\title{
Informed choice? How the United Kingdom's Key Information Set fails to represent pedagogy to potential students
}

\author{
Helen Barefoot, University of Hertfordshire, UK; 01707284000, h.barefoot@ herts.ac.uk \\ Martin Oliver, UCL Institute of Education, UK; 0207763 2168, m.oliver@ioe.ac.uk \\ Harvey Mellar, UCL Institute of Education, UK; h.mellar@ioe.ac.uk
}

\begin{abstract}
This paper explores the ways in which information about course pedagogy has been represented to potential students through national descriptors and specifications such as the United Kingdom's Key Information Set. It examines the extent to which such descriptors provide helpful information about pedagogy, for example innovative uses of technology. The paper starts by exploring the wider context within which these descriptors have been developed, including a comparison of similar descriptions internationally. This is followed by a comparative analysis, in which two courses (one single honours undergraduate degree, one Massive Open Online Course) are classified and compared. This serves to illustrate the blind spots in classifications such as the Key Information Set. The paper concludes by arguing that further work is needed to develop classification schemes that both address explicitly the interests of potential students and are able to represent the pedagogic decisions that differentiate teaching in contemporary higher education.
\end{abstract}

\section{Keywords}

Key Information Set, student choice, pedagogy, curriculum design, learning design, National Student Survey, higher education, quality

\section{Introduction}

The idea that students are now 'consumers' of higher education is increasingly widespread. One consequence of this idea is that universities should offer potential students sufficient information to make an informed choice about the courses they take: a choice that should, arguably, recognise the influence of pedagogic decisions on students' studies.

In order to explore these ideas, first, contemporary developments in policy and research that relate to the idea of students as consumers will be reviewed. This will highlight the issue of informed course choice. International comparisons will be drawn of the information provided to students, to inform their choice of course. Then, pedagogic developments in contemporary higher education will be outlined, arguing that this has implications both for quality and the student experience. Approaches to representing pedagogic decisions will be identified, and then 
applied to two cases. The paper will conclude by identifying the implications of this analysis for the ways in which information about courses is presented to potential students.

\section{The repositioning of students as consumers}

The idea that students are now consumers of higher education, and that higher education itself now operates as a global market, is well established in policy and in research (Baldwin \& James, 2000). This idea has had a profound effect on the relationship between higher education and the state, as has been widely discussed (Morley, 2003; Naidoo \& Jamieson, 2005; Molesworth, Nixon \& Scullion, 2009; Greatix, 2011; Times Higher Education, 2003), and can be exemplified by the introduction of fees in the previously publicly funded United Kingdom (UK) higher education sector. The implications of this have reached far beyond academic or policy circles, becoming a fixture in the national media. In September 2012, the funding model for English and Welsh universities changed and fees trebled, reaching $£ 9000$ per year. Since the introduction of student fees in 1998 ( $£ 1000$ per year), and the following rise to $£ 3000$ per year in 2004 , debates have played out across national media in which the focus is not whether or not students should be framed as consumers, but primarily on the perceived lack of value for money they get when 'buying' into courses (Doughty, 2007; Wignall, 2007; Hillman, 2014; Sellgren, 2014).

Potter (1998) identifies five key principles of consumerism: access, choice, information, redress and representation. It has been argued that providing more information to prospective students supports their rights as 'consumers' of higher education (Baldwin \& James, 2000). In the UK, for example, the 2011 White Paper Students at the Heart of the System (BIS, 2011) emphasised the importance of choice for prospective students and promised to expand the information available to them. League tables are well-established mechanisms for providing potential student consumers with information about a competitive higher education market, even though such tables vary in their validity, comprehensiveness, comprehensibility, relevance, and functionality (Dill \& Soo, 2005). Within the UK, league tables published by national newspapers (Guardian, Times and Sunday Times) have been used by prospective students to compare institutions based on factors including student performance, staff student ratios and employability, despite doubts about the reliability of these rankings. There have even been attempts to explicitly rank universities according to value for money. For example, Simple Landlords Insurance published The Student Value for Money Report (2012), which ranked universities to demonstrate the best and worst value for money based on academic league tables, tuition fees and average rental costs (Simple Landlords Insurance, 2012).

Given the prevalence of such league tables, and the contribution government policy makes to institutional success in these rankings (Dill \& Soo, 2005), such approaches have become part of national policies. For example, the Higher Education Funding Council for England (HEFCE) acknowledged the importance of informed choice for prospective students and identified it as a key objective for learning, teaching and student choice in their 2011-15 business plan: 
to extend and enhance the information about higher education that is available for students, prospective students and others with an interest (including careers advisers, students' families and employers) (HEFCE, 2011, p. 10).

In 2008, the HEFCE Board and its strategic committee for teaching, quality, and the student experience (TQSE) set up a sub-committee to investigate concerns raised over the quality of English higher education. The sub-committee's recommendations included the following statement:

Public information has much greater potential to be used to educate and inform the public about all aspects of HE, including both academic and non-academic aspects of student life... Reforming the provision of public information will require changes to its content, format and location. (HEFCE, 2009, p. 52)

Consequently, in 2010, HEFCE commissioned Oakleigh Consulting and Staffordshire University to carry out independent research into the information needs of users of public information about UK higher education. They produced a report, Understanding the Information Needs of Users of Public Information About Higher Education (Renfrew et al., 2010). The research considered what information is wanted and needed, the best modes of delivering that information, who should provide the information and how the information would support potential students in making their choice of where to study. As the culmination of this process of consultation and research, HEFCE instituted the requirement that universities produce standardised, qualitycontrolled data: a common 'Key Information Set' (KIS) about their courses. This first became available to students in September 2012.

The Unistats website (….) through which KIS can be accessed enables side-by-side comparison of courses, providing prospective students with visual snapshots of degree courses at different institutions. The KIS includes data associated with student satisfaction from the National Student Survey (NSS) and their satisfaction with the Student Union, employability data from the Destination of Leavers in Higher Education (DLHE) survey, contact time of learning and teaching activities (including patterns of study) and assessment types (coursework, practical and examination). The media coverage of the development of KIS again emphasised the consumerrights element associated with informed choices (Coughlan, 2011).

Early evaluation of user experiences (Hooley et al., 2013) suggested that users (including prospective students, parents or carers, teachers and higher education staff) recognised the value of a comparison site and most users found it easy to use to compare courses in what they considered to be an objective manner.

However, the compilation of information required for the KIS was not straightforward for institutions (Benfield, 2013); the most challenging and resource-intensive parts of this process 
were those that involved capturing programme data relating to learning, teaching and assessment. Institutions indicated difficulties interpreting the definitions of teaching activities and assessment modes as well as understanding how to compile data for distance-learning courses in particular. It is unclear as to how useful the data regarding learning and teaching activities and assessment modes is to prospective students: Hooley et al's. (2013) initial study did not explore in detail how the data was considered by users.

Before the development of the KIS, indeed since 2006, the Higher Education Policy Institute, amongst others, has conducted an annual survey to investigate the academic experience of students at English universities. The surveys have enabled analysis of whether students have received a 'better' academic experience since paying more for their education. Measures such as contact time with staff, teaching group size and quality of teaching facilities have been considered. Despite the trebling of fees, the 2014 survey, in alignment with previous surveys, suggests that although students now pay more, they do not consider their experience of higher education to have improved in line with these fee increases, because they do not consider themselves to be receiving 'more' for their money. 'More', in this context, refers to the quantity of contact hours: the survey shows that these have increased only marginally since the survey began; 13.75 hours per week (for first and second year students) in 2006 to 14.15 hours per week in 2014 (Soilemetzidis et al., 2014).

The focus on contact hours in the Higher Education Policy Institute survey and in the KIS may however be misleading: contact hours are an obvious measure of what students get in return for their fees, but they consider quantity not quality. The value of such hours to the student may vary considerably, being influenced by the style of teaching, the subject, and the size of class and the level of study. Moreover, contact hour calculations fail to account for the full range of learning activities that a course or programme may involve, including, for example, the degree of guided independent study, such as that facilitated through technology use.

The 'gap' experienced by students between expectations and their initial experiences is an important influence on students' satisfaction with, and success in, higher education (Forrester \& Parkinson, 2006). Students expect to become more independent learners than they were before they went to University, and realise they will have an increased workload compared to school or college (Oliver et al, 2014); however, fewer recognise the common assumption that they will be fluent users of technology; an issue that causes sufficient stress that some students consider leaving their courses as a result (Leese, 2010). Potential students' expectations are that technology provides a means to access resources and support studying; they do not seem to see technology as having pedagogic implications (Kandiko \& Mawer, 2013). The concerns that students do have are primarily about access and administration: wifi provision, Internet access, being able to bring their own devices onto campus, to have access to desktop computers and printers, an institutional email address, and to have course information provided in a consistent 
manner via the institutional virtual learning environment, but also to have training in the use of these, and to have teaching staff who are fluent users of relevant technologies (Beetham \& White, 2013). Beetham \& White's study shows that students expect technology to be incorporated in a way that they describe as "relevant" to their academic success, but could not explain these expectations because they were not clear what such relevance would actually entail.

\section{Information provision: international comparisons}

The situation in the UK provides a clear example of the issues around informed choice for potential students but similar challenges are recognised internationally. The International Network for Quality Assurance Agencies in Higher Education sets out a general requirement for public accountability that requires certain kinds of information about institutions to be made publicly available (INQAAHE, 2007). At the European level, the Standards and Guidelines for Quality Assurance in the European Higher Education Area (ESG) (Thune, 2005) include a standard for public information, with the accompanying guideline suggesting that:

institutions provide information about their activities, including the programmes they offer and the selection criteria for them, the intended learning outcomes of these programmes, the qualifications they award, the teaching, learning and assessment procedures used, the pass rates and the learning opportunities available to their students as well as graduate employment information" (ENQA, 2015, p. 12)

The work done for HEFCE in 2010, in preparation for the development of the KIS, identified important points of comparison with data provided by public and government bodies in the United States of America (USA), Canada and Australia. To bring this international comparison work up to date, new internet searches were undertaken in order to identify relevant data sets maintained by government bodies in English speaking countries. A small number of similar data sets in non-English speaking countries were also identified. This identified several exemplar national systems that would be useful comparators: Australia (Australian Department of Education, n.d.), Canada (Government of Canada, n.d.), USA (U.S. Department of Education, n.d.; National Centre for Educational Statistics, n.d.), Chile (Ministerio de Educación, n.d.), Denmark (Ministeriet for Børn, Undervisning og Ligestilling, n.d.) and Sweden (Swedish Council for Higher Education, n.d.). Searches for comparable sites and services were undertaken for other countries, and these were followed up by contacting in-country practitioners, but no further national systems were identified that provided consistent national access points for potential students to information about universities.

In this section, these different approaches to the provision of information to prospective students will be briefly reviewed. 


\section{National data sets}

Although all universities covered by these schemes appear to provide some information about their courses in accordance with international guidelines, in most countries there is little attempt to facilitate comparisons between universities or courses. Where systems do exist they generally allow users to search for courses based on subject, location, costs and rankings according to some national (or international) scale. Very few provide any information about pedagogy or student satisfaction data.

Outside the UK, the information available in the USA was found to be the most detailed. The College Scorecard (U.S. Department of Education, n.d.) gives information on costs, graduation rate, loan default rate, borrowing, and employment destination data. The College Navigator (National Centre for Educational Statistics, n.d.) provides some of the same financial data but also provides information on admissions policies, available majors, accreditation, varsity athletic teams and campus security. However, there is some degree of doubt about the completeness of this information, for example Lederman and Jaschik (2014) found in a survey of university presidents that whilst a half agreed that it was 'appropriate for the federal government to collect and publish data on career and other outcomes of college graduates' only $13 \%$ believed that the data was likely to be accurate.

In comparison to the UK data, the US data sets put greater emphasis on information at the institutional level, with little information available at the course level. The US data sets give more emphasis to the financial aspects, and also include information on varsity athletic teams, and institutional security (such as reported crime rates) which is not provided in the UK data, which does however include information on the Student Union, perhaps reflecting specific national interests.

\section{Non-governmental information systems}

Whilst not directly relevant to the main thrust of the argument of this paper it is worth noting that the lack of comparison data in national information systems has led to a variety of nongovernmental bodies attempting to provide such comparisons using approaches in which the potential student is clearly positioned as consumer. This includes the production of league tables by UK national newspapers noted earlier. To gain a more complete understanding of the information available to potential students, it is important to be aware of the kinds of systems offered in this way.

For example, one popular comparison site in the USA is provided by Forbes (Forbes, n.d.). They argue that what makes their site distinctive is that their ranking is distinctive because it takes a more holistic view of what students get from their college experience, rather than focusing purely on metrics such as input measures such as Scholastic Aptitude Test scores or 'return on investment' in terms of average earnings offset against institutional fees (Howard, 2014). Other 
related services within the US include the comparison services provided (for a fee) by the U.S. News (U.S. News, n.d.), or the more proactive services provided by College Coach (College Coach, n.d.), which provides advisors to help students choose the right colleges and courses and offer advice on finance and admissions.

There is a particular demand for comparison data at the European level because of the great variety of course offerings across this region. An example of a site set up to guide students through this choice is Study Portals (Study Portals, n.d.), which provides detailed information on individual courses together with student reviews.

\section{Student feedback in national data sets and how it represents pedagogy}

One important element of national data sets is student feedback. This is often gathered in an unstructured way, and national-level comparisons of institutions are uncommon, though examples can be found in the USA, Australia and the UK (Richardson, 2005). The majority of other data sets examined did not include any equivalent information.

In the UK, the KIS incorporates responses from the NSS, and in the USA a significant number of institutions make use of information from the National Survey of Student Engagement (NSSE). The NSSE has also influenced the Australasian Survey of Student Engagement (Coates, 2010), which is increasingly being taken up in Australia and New Zealand.

Although the data from the NSS and NSSE do not provide direct representations of pedagogy, they do provide some student feedback on pedagogy, which can act as a proxy measure.

Callender et al. (2014) described the purposes of the UK's NSS as being to: inform prospective student choice; enhance the student academic experience within higher education institutions; and ensure public accountability. The NSS was introduced in 2005 and, although not defined as a satisfaction survey, responses to the final question (which relates to overall satisfaction) show a close relationship to the responses to the other 21 questions. The NSS is reported at both institutional level and also at the course level (and these results are used within the KIS). Over the years in which the NSS has run, students have become more satisfied, with the 2014 results achieving a ten-year high with a sector average score being $86 \%$ for overall satisfaction (HEFCE, 2014), a level that that was maintained in 2015 (Times Higher Education, 2015) despite the large increase in fees. However, not all areas of provision are equally well rated; for example, feedback on assessed work is an area where satisfaction is consistently rated as low (Williams \& Kane, 2008). Moreover, as an approach to informing student choice it remains problematic, as research has shown. For example, close analysis of the NSS dataset suggest that there is much more variation in responses from students within each university than there is between institutions, and that analysis at the level of courses becomes unreliable (Cheng \& 
Marsh, 2010). Moreover, despite apparent student satisfaction improving, the number of formal appeals and complaints against universities by students has also increased (Ratcliffe, 2013).

While the NSS gathers opinions from students about their experiences on their courses, the National Survey of Student Engagement (NSSE, n.d.) in the USA gathers information about students' participation in learning activities. The NSSE describes its goals in this way:

Student engagement represents two critical features of collegiate quality. The first is the amount of time and effort students put into their studies and other educationally purposeful activities. The second is how the institution deploys its resources and organizes the curriculum and other learning opportunities to get students to participate in activities that decades of research studies show are linked to student learning.

The NSSE provides institutions with comparison reports for ten engagement indicators (higherorder learning, reflective and integrative learning, learning strategies, quantitative reasoning, collaborative learning, discussions with diverse others, student-faculty interaction, effective teaching practices, quality of interactions, supportive environment) and for six high-impact practices (learning community or some other formal programme where groups of students take two or more classes together; courses that included a community-based project (servicelearning); work with a faculty member [academic member of staff] on a research project; internship, co-op, field experience, student teaching, or clinical placement; study abroad; culminating senior experience (which could include a capstone course, senior project or thesis, comprehensive examination or portfolio).

Since 2013, institutions have also been able to opt to include specific topical modules on learning with the NSSE survey. One of these optional set of questions relates to 'learning with technology' and asks about the role of technology in student learning, focusing on usage, contribution to learning, and perceptions of institutional support.

Not all US institutions take part in the NSSE. Of those that do, most use the data internally to help benchmark their offerings and improve what they offer but do not routinely make the data publicly available. Where the NSSE results are reported it is at the institutional level rather than at course level (though it is possible to obtain analysis of the data by the degree major). The NSSE information is only reported publicly in an aggregated form and the detailed information on individual institutions is provided privately to the organisations using the NSSE. However, NSSE encourages institutions to share this information with prospective students, and provides 24 examples of institutions who have done this on its website.

\section{Summary of international comparisons}

Internationally there is significant variation in the kind, extent and consistency of information provided to potential students. The NSSE provides perhaps the most detailed picture of students' 
perception of pedagogy. The UK KIS is distinctive in both the extent to which this particular set of information has been mandated nationally and in the granularity of information, which is available at the course level rather than just the institutional level. However, concerns remain about whether or not the information provided by the KIS is sufficient to base significant commitments of time and money upon and so, in the next section, one specific issue (the use of technology to enhance learning) will be examined, which illustrates the limitations of the KIS in providing representations of contemporary course pedagogy.

\section{Quality, technology and pedagogy}

Although there is little consideration of technology in the national data sets, the relationship between technology use, educational quality and the student experience has been explored quite extensively elsewhere. It has been established over several decades that simply adding technology does not improve education; or indeed, make it worse: the 'no significant difference effect' has remained stubbornly consistent (Russell, 1999). Where technology has been linked to improved educational outcomes, this was due to more careful pedagogic design, not technology per se (Means et al., 2009).

The use of technology is often associated with changes to practice, some of which may be unanticipated or unplanned. Such changes are often rhetorically associated with 'enhancement', suggesting simply the improvement of existing practices but such discourses are often vague and only weakly linked to evidence (Kirkwood \& Price, 2014). Whilst technology may be introduced as an educational 'fix' for a specific problem, it frequently leads to a more fundamental reconsideration of pedagogy, and of the relationship between teacher and learner.

E-learning is often talked about as a "trojan mouse", which teachers let into their practice without realizing that it will require them to rethink not just how they use particular hardware or software, but all of what they do. (Sharpe \& Oliver, 2007, p. 49)

What is required, then, is a close analysis of the kinds of pedagogic change that take place alongside the introduction of technology. Such analysis is missing from national frameworks but has been developed in the field of learning design, which explores the pedagogic roles that technology is intended to support. These developments have drawn on the idea of design patterns, an approach developed in architecture, 'to democratise architecture and town planning by offering a set of conceptual resources that ordinary people could use in (re)shaping their environment' (Goodyear, 2005). These patterns are intended to stand as formalised solutions to pedagogic problems; under the rubric of 'learning design', it has been proposed that patterns such as these can be used to develop a repertoire of tried-and-tested pedagogic approaches that can be combined and adapted to form programmes of study and to do this by representing pedagogic decisions (including technology use) in a way that can be shared, refined, and even quality assured (Laurillard, 2008). Examples of this include the executable sequences developed 
for software environments such as Learning Activity Management System (LAMS) (Laurillard, 2012, p. 222).

One of the most developed approaches to learning design is outlined by Laurillard et al. (2013, p. 15). This account seeks to explore how 'a specially developed computational environment could support the process of designing conventional, digital, and blended learning', by providing a 'microworld' in which different pedagogic approaches can be modelled, and the implications of these for students' patterns of learning explored. This is done by eliciting proposed pedagogic designs from teachers and analysing the percentages of students' time spent in acquisition; inquiry; discussion; practice; and production. (Later developments of this approach have also added collaboration as a category.) These percentages are represented back to the teacher, for example in the form of a pie chart, 'which provides a visual impression of the distribution of types of learning, rather than numbers, avoiding an unwarranted precision' (Laurillard et al., 2013, p. 24).

However, whilst this is useful as a stimulus for reflection by teachers, it is not clear how useful it would be as a way of informing potential students about courses. In these designs, the distribution of students' time across these activities is a 'best guess', based on the intentions of teachers. It does not necessarily represent what students do either on average, or in specific cases. Nor does it relate instances of these designs to students' experiences of study. This suggests that attempts to extend the use of this representation beyond its current focus may be problematic.

Even if it were desirable to populate these designs with information about students' actual study practices, it would not be easy to implement. Exploration of students' actual engagement in higher education shows that this is complex, highly variable, improvised and constantly negotiated. For example, much of it takes place outside conventional institutional boundaries. It is widely distributed, taking place within institutional buildings but also in networked study bedrooms that were described as 'learning nests' (Jones \& Healing, 2010), as well as in parks, cafés, on public transport and in the bath, not to mention placements in schools and similar sites (Oliver \& Gourlay, 2013). Some of these are clearly outside institutional responsibilities, others clearly inside, but overlaps occurred with resources and services provided by the institution but used in a range of settings, such as provision of digital resources or access to virtual environments. How then can the students who create their own experiences be recognised as a source of motivation, power, knowledge and legitimation (Houston \& Paewei, 2013)? What are an institution's responsibilities when students are recognised as learning independently?

Mapping actual student practice may be beyond the short-term scope of such approaches; however, there may still be value in using this form of representation to explain course design to prospective students. In the next section, case studies will be presented that compare courses 
using examples of these different representations, in order to explore the relative strengths and shortcomings of each.

\section{Case Studies}

The review of data provision internationally showed that practice varies considerably, but that the UK's KIS provides a relatively advanced set of data, and is distinctive in that it does so at the level of courses rather than institutions. However, as the previous section has shown, there are concerns about whether systems such as this go far enough in informing students about the kinds of educational experience that they should expect.

How useful are the KIS categorisations when considering learning activity and assessment? In order to explore this concern, in this section, two case studies are presented. Each will be analysed twice: once using the approach that underpins the KIS and once using the kinds of classification developed in the context of research on learning design, in order to contrast what each is able to represent.

Within Unistats (Unistats website, n.d.), data relating to how courses are taught are presented under the following three headings according to each year of study:

- percentage of time in lectures, seminars and similar;

- percentage of time in independent study;

- percentage of time on placement (if relevant to course).

Assessments modes are also presented according to year of study via the following categories:

- percentage coursework

- percentage written examinations

- percentage practical examinations

To gain a contrasting perspective, the teaching and assessment activities in each case have also been analysed using Laurillard et al.'s (2013) Learning Designer tool, which identifies six types of learning:

- acquisition (receiving information);

- practice ;

- production;

- inquiry;

- discussion;

- collaboration. 
This analysis consists of developing a description of the teaching and assessment activities, and then classifying each activity against the type or types of learning that best describe what the student does during that activity. These classifications are weighted against the description, to reflect what will happen during the activity. The amount of time the students then spend on each activity is distributed proportionally across the different categories, to develop an aggregated profile of the pedagogy of the programme.

Each case is presented separately, below.

\section{Case one}

The first case focuses on a typical single honours undergraduate three-year course taught at a post-1992 UK University (BSc Honours degree of an Earth Sciences discipline). The course includes fieldwork, practical classes, lectures and tutorials. There are collaborative assignments and blended learning activities as well as written- and presentation-based assessments. The course includes 15 credit point modules and 30 credit point modules, each of which includes elements of contact activity and independent learning activity. Under the KIS categorisation the programme teaching activity can be seen in Figure 1.

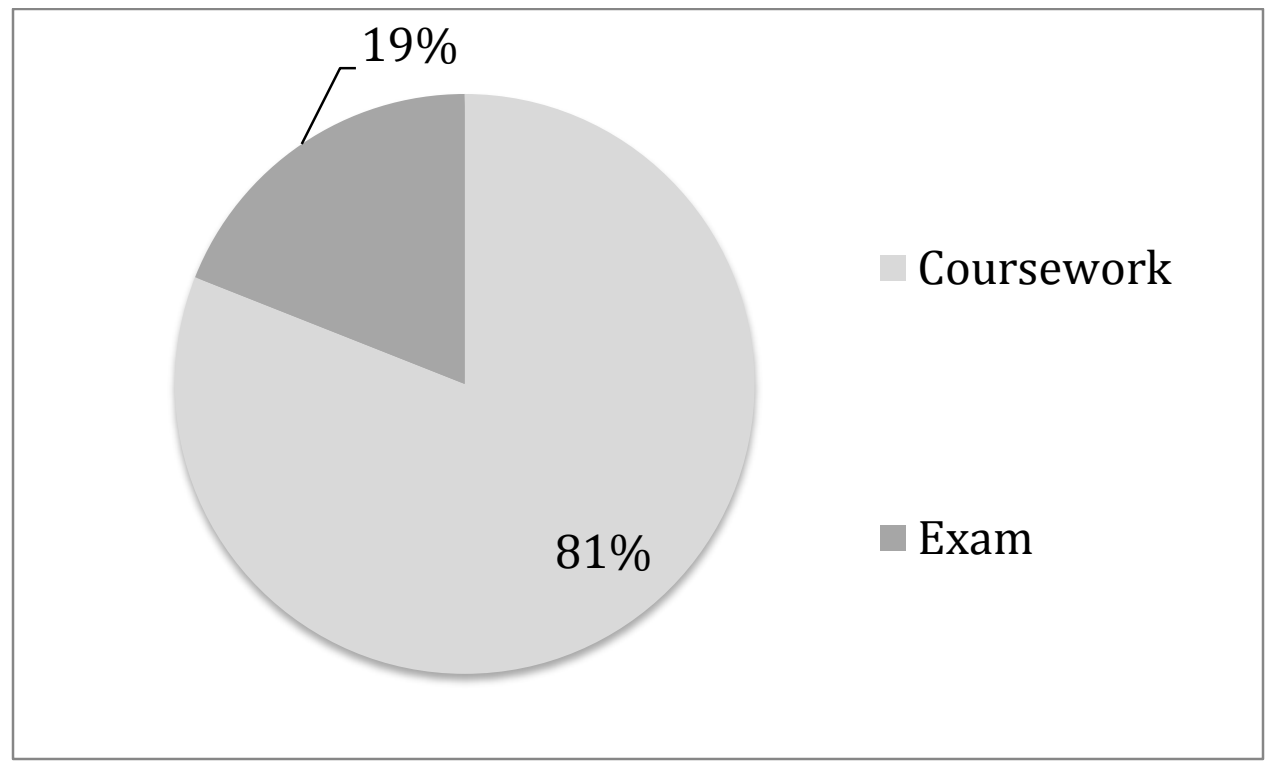

Figure 1: Pie chart to show how the undergraduate course is taught according to KIS categorisation

Assessment within the programme, which includes collaborative fieldwork, an individual research project, multimedia presentations as well as individual written assignments and oral presentations is presented according to KIS categories in Figure 2. 


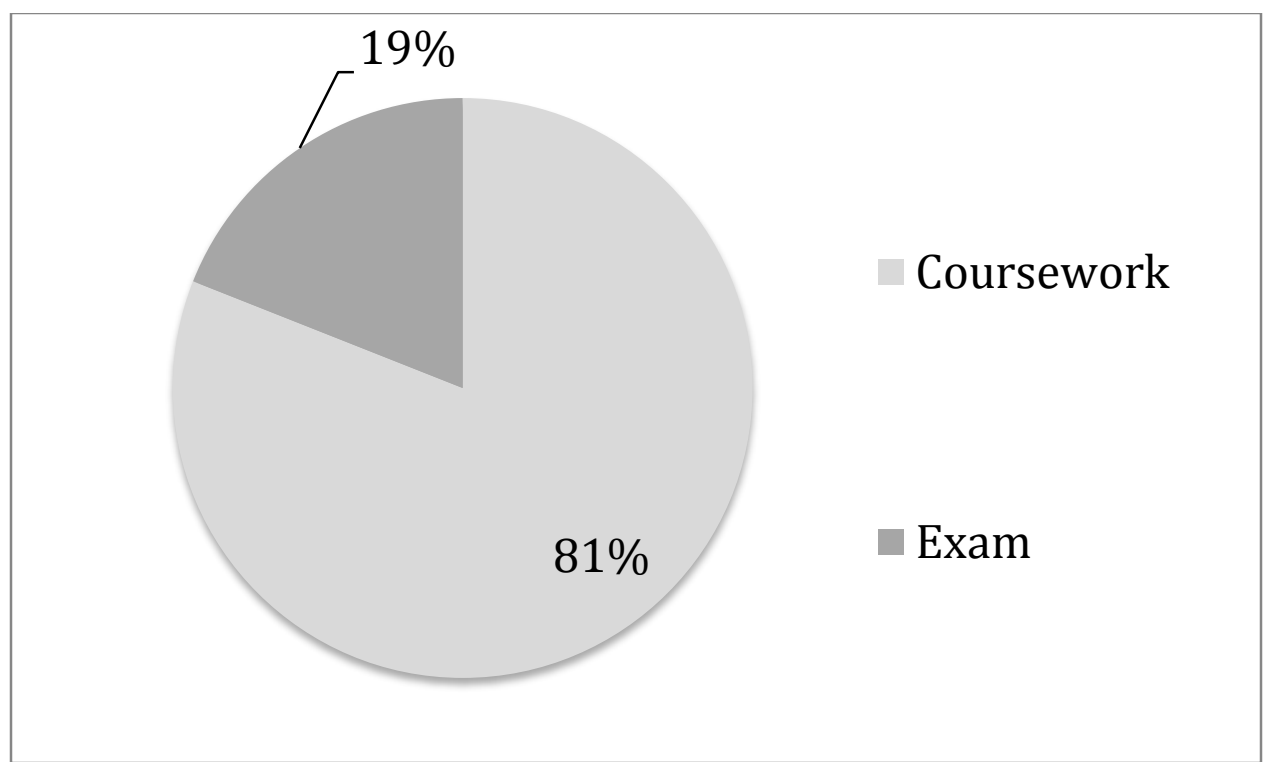

Figure 2: Pie chart to show how the undergraduate degree is assessed according to KIS categorisation

It is evident that the KIS pie charts provide relatively little detail about the range of learning and assessment activities and no indication as to the collaborative assignments or the technology enhanced learning activities included in the programme.

To provide a contrasting perspective, the same case was also analysed using the six categories identified in the Learning Designer framework. This does not explicitly distinguish between teaching and assessment activities but does enable different types of learning to be identified, some of which form part of the assessed work (for example, collaboration activity is based on group activities in taught classes and via assessed group reports and presentations). 


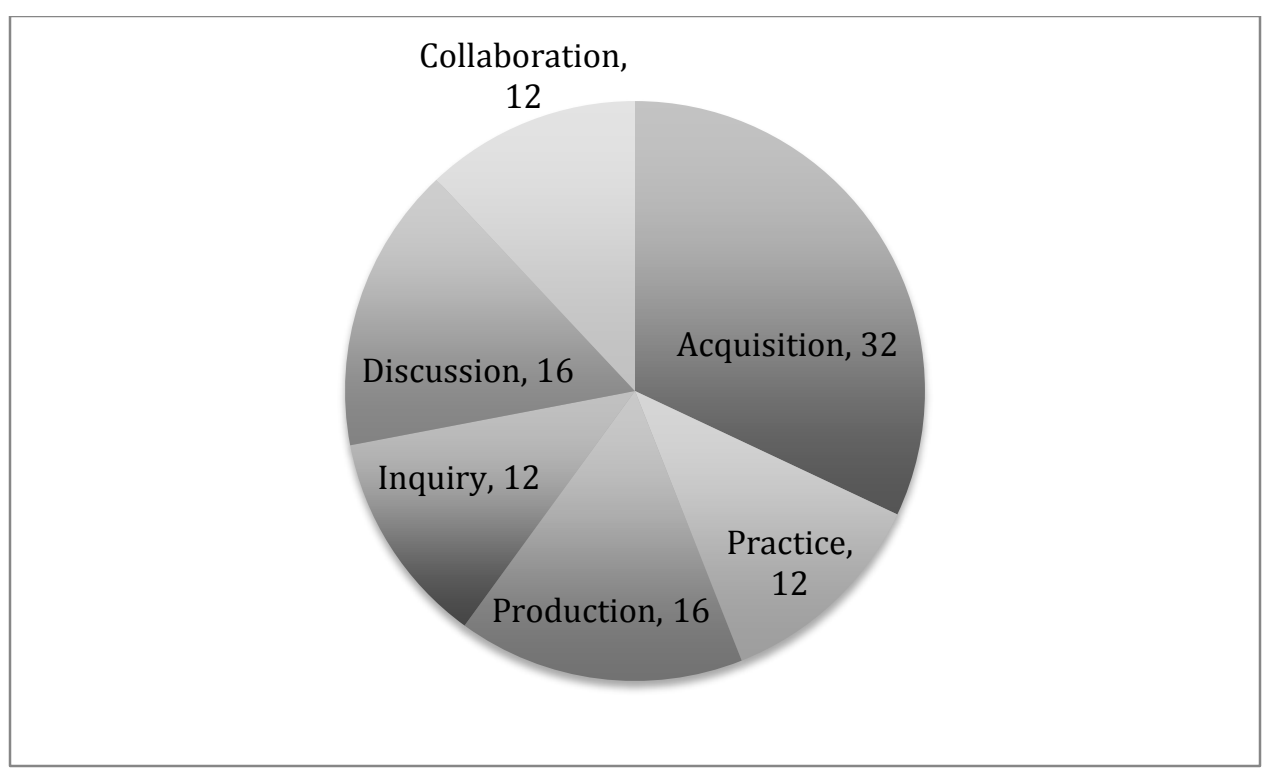

Figure 3: Pie chart to show learning activities within the undergraduate course

The categorisation of the undergraduate course (Figure 3) provides a much richer picture of learner activity. Whilst this is intended to inform course design, it does appear consistent with the general principle of providing students-as-consumers with richer information about their options (Baldwin \& James, 2000).

However, the Learning Designer categorisation does not provide an indication as to how much of the teaching is contact based, how much of the learning is directed self-study taking place beyond the classroom, how much is independently directed and how much is online or blended learning. Also, the Learning Designer tool seems to be primarily aimed at session level rather than at module or course level. Categorising a whole undergraduate programme using the Learning Designer, proved very challenging and required a certain degree of estimation, for example, when considering collaborative discussion time within lectures. There may, therefore, be a balance to be struck between the value of the representation and the effort taken to produce it. Whilst there is support from lecturers for the idea of analysing the quality of programme designs in the form of a pie-chart of the percentage of types of learning it facilitates (Laurillard et al, 2013), given that institutions have already found compiling information for the KIS teaching and assessment categories to be challenging (Benfield, 2013), it may prove unrealistic to produce the richer, more nuanced data required by the Learning Designer.

\section{Case two}

In order to test the limits of the KIS categorisation, it is useful to look at boundary cases. For online provision, the KIS categorisation breaks down completely. For example, when analysing a Massive Open Online Course (MOOC) on educational technology, the KIS categorisation 
implies that there is no teaching, classifying all time as 'independent study' and also classifying all assessment as coursework. (No figures have been produced for this since the pie charts equivalent to Figure 1 and 2 would each have only one category.)

This bluntness is self-evidently unhelpful in supporting any kind of informed choice on the part of potential students.

By contrast, when using the Learning Designer categorisation, the richness of learning and assessment activity becomes more visible, highlighting the collaborative and constructivist approach intended within the MOOC (Figure 4).

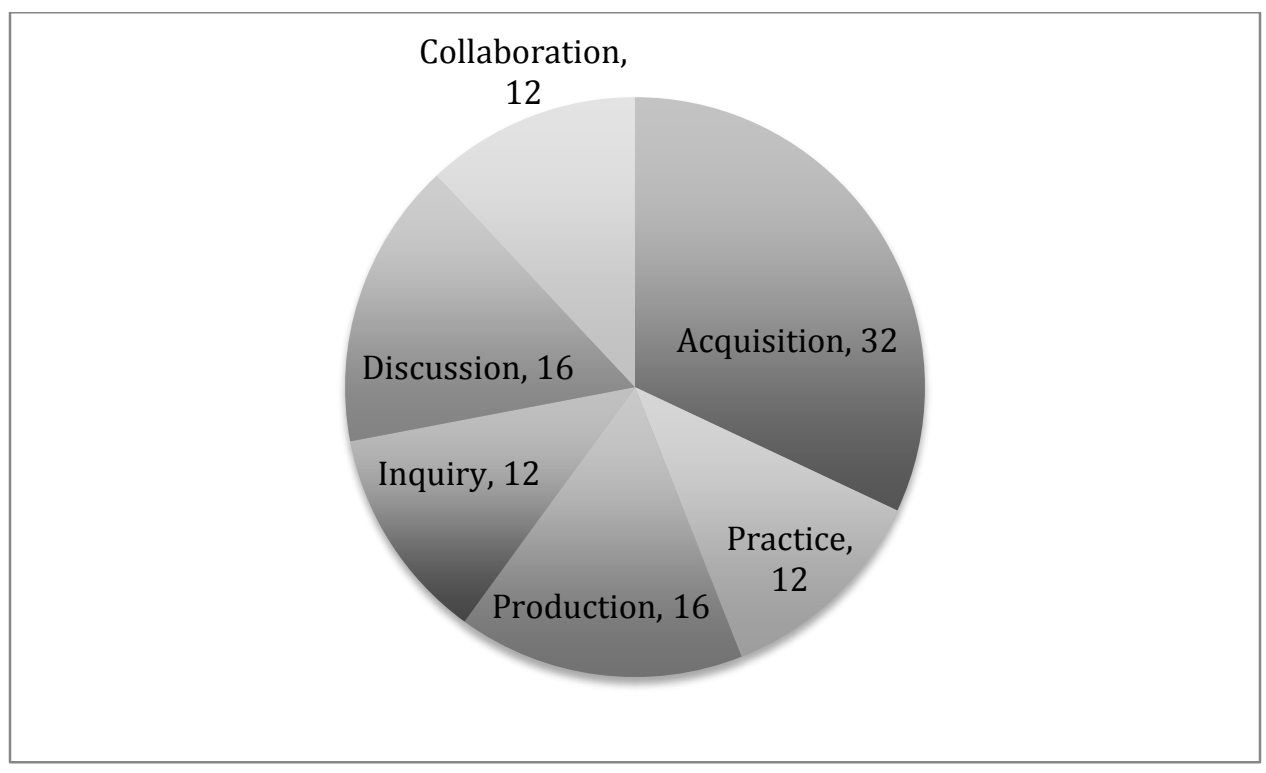

Figure 4: Pie chart to show learning activities within the MOOC

Comparing an online course with a face-to-face course, it is evident that the Learning Designer classification, which does not distinguish between mode of delivery, enables appropriate comparison of the learning experience, which the KIS does not.

\section{Conclusions}

Several schemes have been established internationally to provide prospective students with information about possible courses of study. A review of these has shown considerable variation between them: the data provided; whether it is nationally mandated, a local arrangement or provided by a private interest; and even what level of granularity the scheme operates at. Although the UK's KIS represents a relatively developed, systematic approach to such provision, even this faces several questions and challenges. However, despite HEFCE's aim to expand and 
enhance the information provided by HEIs via KIS, any actual impact on consumers remains to be established. It is not yet clear whether this is simply a consequence of the relatively short period within which the KIS has been available, a lack of evaluation and research about consumer use of the KIS, or that the information provided is not actually what stakeholders require.

Specifically, it remains unclear how the way learning and teaching activities, contact hours and assessment types are represented to potential students affects their subsequent choices. However, it has become clear that the classification of study modes and teaching methods is having an impact on curriculum design within institutions. In particular, the inability to represent the use of technology can be seen as under-valuing, even discouraging, innovation. If these descriptors are intended to cover an increasing proportion of university provision, this will become a particularly acute issue as postgraduate and professional courses (where online learning is most prevalent; (White et al., 2010)) are brought under its scope.

Technology is clearly an important aspect of all contemporary higher education provision, even within courses conventionally framed as being face-to-face. High expectations around students' technological fluency are influencing the success of their transitions into higher education; widespread use of technology on courses is also changing their experiences of study. None of this is reflected within the current KIS scheme, or indeed, any of the other national systems that were identified.

As illustrated by the case studies above, the KIS classifications simply fail to provide useful information about courses that are technologically innovative, serving to normalise conventional class-based formats, irrespective of their pedagogic merit. New developments such as MOOCs are poorly served by this system; as are potential students, who will be unable to distinguish between the very transmissive pedagogies many MOOCs rely on and the more individualised, supportive educational experience that are to be found in other online degree provision. Unless this issue can be represented to students in a way that they find meaningful, this will simply compound the current conservative position in which 'Institutions should be cautious of using technology as a replacement for face-to-face interactions, or as a substitute for developing an active and collaborative learning environment and community' (Kandiko \& Mawer, 2013: 72), because prospective students value the quantity of face-to-face provision over the pedagogic quality of the course design.

By contrast, the kinds of pedagogic classifications developed in the context of Learning Design do successfully represent such pedagogic decisions. These too have their limitations; the classification scheme developed by Laurillard et al. (2013) and used in the analysis of the cases here would be time consuming to use at the programme level, and remains deliberately blind to whether elements of a course are online or face-to-face: an issue that potential students may well 
be interested in. This suggests that further work is needed to develop schema that can incorporate representations of pedagogic approach; reflect the ways in which programmes are online or faceto-face; and, ideally, that provide data about students' patterns of engagement (what studying a programme actually requires of learners) rather than only their satisfaction.

However, even if these points can be addressed, challenges remain. The principle behind information provision is to support choice, building on the assumption that students are acting as informed consumers when they apply for their degree. Whilst there is evidence that students are indeed adopting a more consumerist orientation towards higher education, the relationships between fees, quality and value are not well understood, and framing this decision purely financially may miss social, cultural or intangible aspects of the decision (Kandiko \& Mawer, 2013). The influence of course information on this choice warrants further investigation. It is important to be clearer about what institutions want to tell potential applicants; but it is still not yet clear what they actually want to know.

\section{References}

Australian Department of Education, n.d., http://home.education.gov.au/myuniversity.html (Accessed 19 October 2015).

Baldwin, G. \& James, R., 2000, 'The market in Australian higher education and the concept of student as informed consumer' Journal of Higher Education Policy and Management, 22(2), pp. $139-48$.

Beetham, H. \& White, D., 2013, Students' Expectations and Experiences of the Digital Environment. Bristol: JISC. Available at http://repository.jisc.ac.uk/5572/1/JR0006_STUDENTS_EXPECTATIONS_EXEC_SUMMAR Y_v2.pdf (Accessed 12 November 2014).

Benfield, C., 2013, Early Evaluation of KIS/Unistats Institutional perspective. Cheltenham: Higher Education Statistics Agency.

Callender, C., Ramsden, P. \& Griggs, J., 2014, Review of the National Student Survey. Bristol: Higher Education Funding Council for England.

Cheng, J. \& Marsh, H., 2010, 'National Student Survey: are differences between universities and courses reliable and meaningful?', Oxford Review of Education, 36(6), pp. 693-712.

Coates, H., 2010, 'Development of the Australasian survey of student engagement (AUSSE)', Higher Education, 60(1), pp. 1-17. 
College Coach, n.d., http://info.getintocollege.com/college-coach-matrix-2013/ (Accessed 12 January, 2016).

Coughlan, S., 2011, 'Students to get best-buy facts and consumer rights', BBC News, 11 June 2011. Available at http://www.bbc.co.uk/news/education-13874483 (accessed 12 November 2014).

Department for Business, Innovation and Skills (BIS), 2011, Students at the heart of the system. London: Department for Business, Innovation and Skills.

Dill, D. \& Soo, M., 2005, 'Academic quality, league tables, and public policy: A cross-national analysis of university ranking systems', Higher Education, 49, pp. 495-533.

Doughty, S., 2007, September 24, 'UK students are least hard-working in Europe', The Daily Mail.

European Association for Quality Assurance in Higher Education (ENQA), 2015, Standards and Guidelines for Quality Assurance in the European Higher Education Area (ESG). http://www.enqa.eu/wp-content/uploads/2015/05/ESG_endorsed-with-changed-foreword.pdf (Accessed 4 October, 2015).

Forbes, n.d., Ranking America's Top Colleges. http://www.forbes.com/top-colleges/list/ (Accessed 12 January 2016).

Forrester, G., \& Parkinson, G., 2006, '"Mind the Gap": The Application of a Conceptual Model to Investigate Distance Learners' Expectations and Perceptions of Induction', Issues in Educational Research, 16(2), pp. 152-170.

Goodyear, P., 2005, 'Educational design and networked learning: patterns, pattern languages and design practice’, Australasian Journal of Educational Technology, 21(1), pp. 82-101.

Government of Canada, n.d., http://tools.canlearn.ca/cslgs-scpse/cln-cln/rep-fit/p/af.p.clseaeng.do (Accessed 12 January 2016).

Greatix, P., 2011, March 13, 'University isn't just a business - and the student isn't always right', The Guardian, Higher Education Network. http://www.theguardian.com/higher-educationnetwork/higher-education-network-blog/2011/mar/14/students-as-consumers (Accessed 12 November, 2014).

Higher Education Funding Council for England (HEFCE), 2009, Report of the sub-committee for Teaching, Quality, and the Student Experience. 
http://www.hefce.ac.uk/media/hefce1/pubs/hefce/2009/0940/09_40.pdf (Accessed 12 November, 2015).

Higher Education Funding Council for England (HEFCE), 2011, Business Plan 2011-2015, Principles, priorities and practices. http://www.hefce.ac.uk/about/plan/ (Accessed 12 October, 2015).

Higher Education Funding Council for England (HEFCE), 2013, Postgraduate education in England and Northern Ireland. http://www.hefce.ac.uk/pubs/year/2013/201314/ (Accessed 12 November, 2014).

Higher Education Funding Council for England (HEFCE), 2014, National Student Survey results hit 10-year high. http://www.hefce.ac.uk/news/newsarchive/2014/Name,94055, en.html (Accessed 11 October, 2015).

Hillman, N., 2014, May 21, 'Sharp rise in students who think university is poor value', The Guardian, Learning and Teaching Hub. http://www.theguardian.com/higher-educationnetwork/blog/2014/may/21/students-think-university-poor-value-for-money (Accessed 12 November, 2015).

Hooley, T., Mellors-Bourne, R. and Sutton, M., 2013, Early Evaluation of Unistats User experiences, Bristol: HEFCE.

Houston, D. \& Paewai, S., 2013, 'Knowledge, power and meanings shaping quality assurance in higher education: a systemic critique', Quality in Higher Education, 19(3), pp. 261-282.

Howard, C., 2014, July 24, 'Ranking America's Top Colleges 2013', Forbes. http://www.forbes.com/sites/carolinehoward/2013/07/24/ranking-americas-top-colleges-2013/ (Accessed 12 November, 2014).

International Network for Quality Assurance Agencies in Higher Education (INQAAHE), 2007, Guidelines of Good Practice in Quality Assurance. http://www.inqaahe.org/admin/files/assets/subsites/1/documenten/1231430767_inqaahe--guidelines-of-good-practice\%5B1\%5D.pdf (Accessed 12 November, 2014).

Jones, C., \& Healing, G., 2010, 'Networks and locations for student learning', Learning, Media and Technology, 35(4), pp. 369-385.

Kandiko, C. B. \& Mawer, M., 2013, Student Expectations and Perceptions of Higher Education. London: King's Learning Institute. https://www.kcl.ac.uk/study/learningteaching/kli/People/Research/DL/QAAReport.pdf (Accessed 11 October, 2015). 
Kirkwood, A. \& Price, L., 2014, 'Technology-enhanced learning and teaching in Higher Education: what is 'enhanced' and how do we know? A critical literature review', Learning, Media and Technology, 39(1), pp. 6-36.

Laurillard, D., 2008, 'The teacher as action researcher: Using technology to capture pedagogic form', Studies in Higher Education, 33(2), pp. 139-154.

Laurillard, D., 2012, Teaching as a Design Science: Building Pedagogical Patterns for Learning and Technology. London: Routledge.

Laurillard, D., Charlton, P., Craft, B., Dimakopoulos, D., Ljubojevic, D., Magoulas, G., Masterman, E., Pujadas, R., Whitley, E.A. \& Whittlestone, K., 2013, 'A constructionist learning environment for teachers to model learning designs', Journal of Computer Assisted Learning, 29, pp. 15-30.

Lederman, D. \& Jaschik, S., 2014, March 7, 'Federal Accountability and Financial Pressure: A Survey of Presidents', Inside Higher Education.

http://www.insidehighered.com/news/survey/federal-accountability-and-financial-pressuresurvey-presidents (Accessed 12 November, 2014).

Leese, M., 2010, 'Bridging the gap: supporting student transitions into higher education', Journal of Further and Higher Education, 34(2), pp. 239-251.

Means, B., Toyama, Y., Murphy, R., Bakia, M., \& Jones, K., 2009, Evaluation of EvidenceBased Practices in Online Learning: A Meta-Analysis and Review of Online Learning Studies, Washington: US Department of Education. https://www2.ed.gov/rschstat/eval/tech/evidencebased-practices/finalreport.pdf (Accessed 12 January 2016).

Ministeriet for Børn, Undervisning og Ligestilling, n.d., https://www.ug.dk (Accessed January 12, 2016).

Ministerio de Educación, n.d., http://www.mineduc.cl (Accessed January 12, 2016).

Molesworth, M., Nixon, E. \& Scullion, R., 2009, 'Having, being and higher education: the marketisation of the university and the transformation of the student into consumer', Teaching in Higher Education, 14(3), pp. 277-287.

Morley, L., 2003, 'Reconstructing students as consumers: power and assimilation?', in Slowey, M. and Watson, D., Higher Education and The Lifecourse, pp. 79-92, London: SRHE and Open University Press. 
Naidoo, R. and Jamieson, I., 2005, 'Empowering participants or corroding learning? Towards a research agenda on the impact of student consumerism in higher education', Journal of Education Policy, 20(3), pp. 267-381.

National Centre for Educational Statistics, n.d., http://nces.ed.gov/collegenavigator/ (Accessed January 12, 2016).

National Survey of Student Engagement. (n. d.). About student engagement. November 12, 2014, from http://nsse.iub.edu/html/about.cfm

Oliver, M., Domingo, M., Hunter, J., Pan, L. \& Gourlay, L. (2014) Pre-tertiary engagement with online learning: Exploring uses of online learning environments and digital technology for progression into and through Higher Education. London: Institute of Education. January 12, 2015, from http://eprints.ioe.ac.uk/19278/.

Oliver, M \& Gourlay, L., 2013, 'Students' day-to-day engagements with technologies: rethinking digital literacies', TEL Ireland Journal, 1(1). http://journal.ilta.ie/2013/05/21/students-day-today-engagements-with-technologies-rethinking-digital-literacies/ (Accessed 12 November, 2014).

Potter, J., 1988, 'Consumerism and the public sector: How well does the coat fit?', Public Administration, 66, pp. 149-164.

Ratcliffe, R., 2013, July 8, 'Students: we can't get no satisfaction', The Guardian. http://www.theguardian.com/education/2013/jul/08/students-fees-consumer-power (Accessed 12 November, 2014).

Renfrew, K., Baird, H., Green, H., Davies, P., Hughes, A., Mangan, J., \& Slack, K., 2010, Understanding the information needs of users of public information about higher education, Bristol: HEFCE. http://www.hefce.ac.uk/media/hefce/content/pubs/2010/rd1210/rd12_10b.pdf (Accessed 11 October, 2015).

Richardson, J., 2005, 'Instruments for obtaining student feedback: a review of the literature', Assessment \& Evaluation in Higher Education, 30(4), pp. 387-415.

Russell, T., 1999, The No Significant Difference Phenomenon as reported in 355 Research Reports. Summaries and Papers: A Comparative Research Annotated Bibliography on Technology for Distance Education, North Carolina State University: Office of Instructional Telecommunications.

Sellgren, K., 2014, May 14, 'Degree courses 'not value for money', say many students', $B B C$ News. http://www.bbc.co.uk/news/education-27486606 (Accessed 12 November, 2014). 
Sharpe, R., \& Oliver, M., 2007, 'Designing courses for e-learning', in H. Beetham \& R. Sharpe(Eds.), Rethinking Pedagogy for a Digital Age: Designing and delivering e-learning, pp. 41-51, London: Routledge.

Simple Landlords Insurance, 2012, 'The student value for money report'.

http://www.simplelandlordsinsurance.com/news/article/001577/the-student-value-for-moneyreport-

2012.aspx?Campaign=AWIN01\&awc=3014_1408100963_3104eaa3dbe58c5bd5f8b758c220f10 9 (Accessed 12 November, 2014).

Soilemetzidis, I, Bennett, P, Buckley, A, Hillman, N \& Stoakes, G., 2014, The HEPI-HEA student academic experience survey, Oxford: Higher Education Policy Institute.

Study Portals, n.d., http://www.studyportals.eu/ (Accessed 12 January, 2016)

Swedish Council for Higher Education (n.d.) http://studera.nu/ (Accessed 12 January 2016).

Swinglehurst, D., Russell, J. \& Greenhalgh, T., 2008, 'Peer observation of teaching in the online environment: an action research approach', Journal of Computer Assisted Learning, 24, pp. 383393.

Thune, C., 2005, Standards and guidelines for quality assurance in the European Higher Education Area, Helsinki: Finland.

http://www.aiknc.lv/static media/dati/materiali/EN/ENQASt280905.doc (Accessed 12 January 2016).

Times Higher Education, 2003, March 7, 'Students win consumer rights', Times Higher Education. http://www.timeshighereducation.co.uk/news/students-win-consumerrights/175179.article (Accessed 12 January 2016).

Times Higher Education, 2015, 12 August, 'National Student Survey 2015: £9K fees fail to dent satisfaction', Times Higher Education. https://www.timeshighereducation.com/news/nationalstudent-survey-2015-9k-fees-fail-dent-satisfaction (Accessed 12 January 2016).

Unistats website, n.d., http://unistats.direct.gov.uk/ (Accessed 12 January 2016).

U.S. Department of Education, n.d., http://www.whitehouse.gov/issues/education/highereducation/college-score-card (Accessed 12 January 2016).

U.S. News College Compass, n.d., http://www.usnews.com/usnews/store/college_compass (Accessed 12 January 2016). 
White, D., Warren, N., Faughnan, S. \& Manton, M., 2010, Study of UK Online Learning, Report to HEFCE by the Department for Continuing Education, Oxford: University of Oxford. http://www.hefce.ac.uk/media/hefce/content/pubs/2010/rd1710/rd17_10.pdf (Accessed 12

November, 2014).

Wignall, A., 2007, Feb 20, 'How to fulfil those great expectations', The Guardian.

Williams, J., \& Kane, D., 2008, Exploring the National Student Survey: assessment and feedback issues, York: Higher Education Academy. 